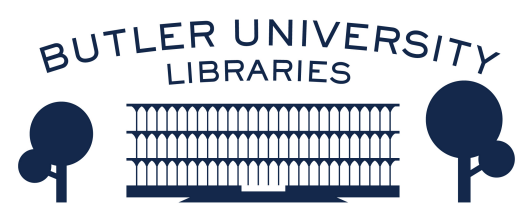

Journal of Hindu-Christian Studies

Volume 23

Article 21

January 2010

\title{
Book Review: "India and the Indianness of Christianity: Essays on Understanding"
}

George Pati

Follow this and additional works at: https://digitalcommons.butler.edu/jhcs

Part of the Religion Commons

\section{Recommended Citation}

Pati, George (2010) "Book Review: "India and the Indianness of Christianity: Essays on Understanding"," Journal of Hindu-Christian Studies: Vol. 23, Article 21.

Available at: https://doi.org/10.7825/2164-6279.1473

The Journal of Hindu-Christian Studies is a publication of the Society for Hindu-Christian Studies. The digital version is made available by Digital Commons @ Butler University. For questions about the Journal or the Society, please contact cbauman@butler.edu. For more information about Digital Commons @ Butler University, please contact digitalscholarship@butler.edu. 
(jnana) is often distinguished from realized knowledge (vijnana), which gurus need to possess. Therefore Hindu gurus cannot be categorized neatly according to the Weberian scheme: they possess both the acquired knowledge, which belongs to the teachers of ethics, and the personally revealed knowledge, which belongs to prophets.

Another shortcoming of Ketola's book is that there is no discussion of the historical development of Gaudiya Vaishnavism to which ISKCON belongs. Following Whitehouse's categorization, the author considers the mode of ISKCON's religiosity doctrinal (Ch. 2 especially). Historically speaking, however, the Gaudiya tradition is mostly known for its imagistic mode of religiosity. The descriptions of ecstasy such as fainting, profuse crying and bursting into laughter are abundant in the hagiographies of Caitanya. According to Rupa Goswami (1489-1564), one of the founding fathers of Gaudiya theology, these symptoms are the results of intense feeling of separation from God. In fact, all Gaudiya ritual practices such as chanting and image worship are intended for the cultivation of one's feeling (rasa) toward God. That the religious mode of such a group might be considered imagistic in Whitehouse's scheme is well supported by Joseph O'Connell's observation that the Gaudiyas traditionally did not accomplish "hard institutionalization" (2004). The promotion of the more doctrinal mode of religiosity within the Gaudiya tradition began only "with Bhaktisiddhanta Sarasvati (1874 - 1937), the guru of Bhaktivedanta Swami, who was responding to the colonial authority's and the British missionary's criticism against the tradition. The doctrinal mode of religiosity is prevalent in ISKCON, since the Swami followed his guru's approach. Had the author kept this historical development in mind, he would not have been surprised to find the imagistic elements in the daily ritual practice in the ISKCON temples (see his discussion in the third chapter).
Nevertheless, The Founder of the Hare Krishnas as Seen by Devotees is a well-rounded research on Bhaktivedanta Swami and ISKCON. The author admirably combines a thorough study of the Swami's and his followers' writings with an extensive participant "observation conducted mainly in Finland. What is more, this study is innovative in that it approaches the subject from a cognitive perspective, which had not been done previously in relation to the study of ISKCON. This approach is particularly illuminating when the author's analysis in the eighth chapter reveals the intriguing psycho-mechanism of religious believers who are forced to reconcile the authority of a charismatic guru with his 'imperfections'. The book is suited for those who are interested in the sociology of religion, modern religious movements, as well as Indic religions in general.

Note

1 http://edition.cnn.com/2010/LIVING/worklife/ 05/16/mf.famous.career.after.50/index.html?iref $=$ allsearch

Bibliography

Carman, John (1981[1974]). The Theology of Ramanuja: An Essay in Interreligious Understanding (Bombay: Ananthacharya Indological Research Institute)

Sharma, B. N. K. (2000 [1961]). History of the Dvaita School of Vedānta and its Literature (Delhi: Motilal Banarsidass)

O'Connell, Joseph T. (2004). Institutionalizing Prema-bhakti

(www.gaudiyadiscussions.com/topic_1446.ht $\mathrm{ml})$

Prabhupada, A. C. Bhaktivedanta Swami. (1982 [1970]) The Nectar of Devotion. (Los Angeles: The Bhaktivedanta Book Trust)

Kiyokazu Okita

University of Florida

India and the Indianness of Christianity: Essays on
Understanding- Historical, Theological, and
Bibliographical- in Honor of Robert Eric Frykenberg. 


\section{Richard Fox Young, editor. Grand Rapids, Michigan: W. B. Eerdmans Publishing Company, 2009, 283 pp.}

THE volume India and the Indianness of Christianity is a compendium of essays in honor of Robert Eric Frykenberg, whose pioneering work on intercultural and interreligious interactions in the South Asian context has exerted considerable influence on historiography. The editor, Richard Fox Young, introduces the volume by discussing Frykenberg's vamsavali or lineage, and methodology that considered Indian Christianity as a social phenomenon. 'Young asserts that though contributors in this volume may not wholeheartedly agree with Frykenberg's perspectives and participation they agree to some extent with his bottom-up historiography that is illuminating and liberating. However, this position places Frykenberg directly at odds with post-colonial and subaltern historical writing on India. Frykenberg's empirical study serves as interlocutor between extreme heuristic approaches that raise pertinent questions regarding the Indianness of Indian Christianity. Despite the different perspectives on this theme they all acknowledge the valuable contribution of Frykenberg, especially the pioneering study of Guntur district. It is the different perspectives of the contributors that make the volume valuable.

The editor has organized the volume into fourteen chapters. Daniel Jeyaraj evaluates the work of the Lutheran missionaries in the Danish colony of Tranquebar in South India (16201845 ) and emphasizes the importance of a "balanced Christian missionary historiography" as it places equal importance to the missionaries and to the "missioned." Both the missionaries needed the Tamil Christians, and the Tamil Christians needed the missionaries for sharing the message of the Gospel in a caste-oriented society. William Shenk discusses methodological issues with regard to the Church Missionary Society's (CMS) involvement with ancient eastern churches in the south Indian state of Kerala under the leadership of Claudius Buchanan (1766-1815), but does not discuss the responses of these churches. The overarching vision to unify Christian churches through world evangelization highlights methodological problems; additionally, the study demonstrates the Western missionary societies' shallow knowledge of ancient churches (pp.57-8). Richard Young's essay studies the case of the nineteenth century author, Ragaviah, and differentiates between 'orientalism', the lateeighteenth and early nineteenth century study of Indian antiquity through its language and literatures, and 'orientalization' the construction of a radical "other" for hegemonic purposes. Young argues that historiography cannot reject the archives and still claim to work with them, because in this way it would sediment voices like Ragaviah (pp. 81). Arvil Powell in his essay examines a learned Muslim convert, 'Abd al-Masih, who, together with the Scotsman Daniel Corrie, initiated a briefly flourishing Christian community in Agra. As an outcome, they forged a new convert community with a unique identity. Anglican missionary activity in Agra among the katra community asserts the uniqueness of the community by considering the new convert community as a social organism (pp.82).

Brian Stanley discusses the life of Henry Martin, whose spiritual discipline of self-denial and scrupulous self-examination expressed his passion for obedience to God's will. These later became the central motifs in the ascetic spirituality of the Oxford movement of the 1830 s and 1840s. More importantly, Martin's New Testament translation was more influential among the natives. Interestingly, his nonwestern admirers appreciated his learning and humility that earned him the title 'man of God;' one filled with divine drunkenness (pp. 125-6). Peter Andersen analyzes the Kherwar movement of the late nineteenth century, which took place among the Santal society, one of the excluded tribal groups in Bihar, just west of Bengal, and argues that a process of syncretism takes place with the incorporation of Hindu and Christian elements, therefore presenting a unique identity. Such an understanding emphasizes how 
Christianity appealed to people in the marginslow-castes, outcastes, and tribals.

Chandra Mallampalli's essay demonstrates the fact that Indian Christianity often tended to adapt itself to the caste system rather than trying to subvert it and critiques Frykenberg's bottomup approach to argue that colonial Raj deindigenizes the indigenized Catholic Church based on court cases pertaining to identity issues among South Indian Roman Catholics. Additionally, he candidly discusses both the methods, from below and above, and leaves the option for historians to employ either approach to tell the story of Indian Christianity, which would have different outcomes. On a different note, Geoffery Oddie contends that the missionaries' contact with Hindu pundits was a significant event in missionary endeavors, but he cautions that there were other factors that played a role in the missionary construction of Hindu religion, as well (pp. 180). Michael Bergunder's essay discusses the problematic issue of proselytism in the history of Christianity in India and states that people changed denominations when a particular denomination of Christianity did not keep up to its promise of providing material incentives. Additionally, change of church affiliation presupposes personal agency-a reason for proselytism in the Indian Christian context (pp. 195). Gunnel Cedarlöf's essay argues that, unlike the other Protestant churches, the European-based Evangelical Lutheran mission had a dual stand on the question of nationalism, partly because they had developed as church missions, built on national churches with a strong resonance of the north European nationalist movements (pp. 198). For this Lutheran mission the late-nineteenth and early twentieth century romantic and nationalistic idea of volk became central in their work and gave the idea of an indigenous Christian nation. As an outcome, the local Tamil Lutherans accepted the caste system as part of their folk character.

Judith Brown discusses how Jawaharlal Nehru, the first Prime Minister of independent India, understood the role of Christians in the new India who were under pressure. Because of Nehru's concern ' about a conception of nationalism that would preclude minority voices, including Christians, he found immensely challenging his promotion of a need for tolerance in a plural society of India, especially because those who controlled state power and public communications had visualized India as less tolerant and less plural than Nehru (pp. 234). John B. Carman's Christian interpretation of Ramanuja, the eleventh century Indian philosopher, sets a valuable paradigm for HinduChristian dialogue highlighting the challenges involved and the complexity of such theological engagement. Carman emphasizes three aspects beneficial for comparative theology: a Christian student of another religion must live in the awareness that theological incorporation of some aspects of Hindu beliefs and practices into Christian life involves an understanding of those elements different from that of the Hindu believer; a Christian scholar must appreciate viewpoints that at times seem similar and at times different; and Christian scholars must be cognizant of myriad Indian Christian perspectives (pp. 239). He concludes his essay with a list of items representing the complexity and challenging task of theological interpretation. The volume concludes with essays by Rosemary Seton and Martha Lynd Smalley that offer extremely useful surveys of archival information for those interested in conducting research in the history of Christianity in India.

George Pati

Valparaiso University

\section{Beyond Boundaries: Hindu-Christian Relationship and Basic Christian Communities. A. Maria David. Delhi: ISPCK, 2009, pp. $\mathrm{xv}+281$.}

$B E Y O N D$ Boundaries is an analysis of "basic Christian communities" established in the diocese of Kottar, district of Kanyakumari (Tamil Nadu), and their potential for helping 